University of Wisconsin Milwaukee

UWM Digital Commons

Geography Faculty Articles

Geography

2016

\title{
Urbanization and rainfall-runoff relationships in the Milwaukee River Basin
}

Woonsup Choi

University of Wisconsin - Milwaukee, choiw@uwm.edu

Kathryn Nauth

Jinmu Choi

Kyung Hee University

Stefan Becker

Follow this and additional works at: https://dc.uwm.edu/geog_facart

Part of the Geography Commons

\section{Recommended Citation}

Choi, Woonsup; Nauth, Kathryn; Choi, Jinmu; and Becker, Stefan, "Urbanization and rainfall-runoff relationships in the Milwaukee River Basin" (2016). Geography Faculty Articles. 10.

https://dc.uwm.edu/geog_facart/10 
1 Urbanization and rainfall-runoff relationships in the Milwaukee River Basin

2

3 Woonsup Choi (iD), Kathryn Nauth, Jinmu Choi \& Stefan Becker

4

5

6 This is an Accepted Manuscript of an article published by Taylor \& Francis Group

7 in The Professional Geographer in volume 68 in 2016, available online:

8 https://www.tandfonline.com/doi/abs/10.1080/00330124.2015.1007427 


\section{Abstract}

12

13 To understand the changing rainfall-runoff relationship, the study examined climate and

14 streamflow data in the Milwaukee River Basin in southeastern Wisconsin, of which four 15 catchments with different degrees of urbanization were selected for analysis. This study 16 analyzed temperature, precipitation, and streamflow data with a range of statistical

17 methods, including the Mann-Kendall test, double-mass technique, and quantile regression.

18 Runoff ratios and extreme flow indices were higher in more urbanized catchments.

19 Catchments with long-term data ( $>40$ years) showed significantly increasing runoff ratios

20 and slopes in double mass curves. Overall, there are signs of changes in the rainfall-runoff

21 relationship, but how much they can be attributed to land use changes is uncertain.

23 Key words: runoff, precipitation, streamflow, urbanization, Milwaukee 
26 The city of Milwaukee and its suburban communities in southeastern Wisconsin suffered

27 significantly from flash flooding events in July 2010. Particularly, the rainfall of $190 \mathrm{~mm}$

28 over a two-hour period on 22 July 2010 turned many streets and roads impassable and

29 caused sewer backups. In response, the President of the United States issued an Individual

30 Assistance Declaration in response to the damage (FEMA 2010). The severity of the

31 flooding events raised some important questions, such as to what extent they were

32 exacerbated by urbanization, and whether such events will occur more frequently in the

33 future. Not far from Milwaukee, urbanizing catchments in northeastern Illinois experienced

34 increases in design peak flows along with increasing precipitation, but on average

35 urbanization contributed more than the increase in precipitation to the increases in peak

36 flows (Hejazi and Markus 2009). Even though the hydrometeorology of particular flood

37 events in the metropolitan Milwaukee region was investigated (e.g. Elsner, Drag, and Last

38 1989; Zhang and Smith 2003), little research investigated long-term relationships between

39 climate and streamflow in the region, taking land use changes into account. It is important

40 to detect past trends of hydroclimatic variables for understanding potential future change

41 and its impacts (Claessens et al. 2006; Sahoo and Smith 2009). The present study

42 investigates the long-term relationship between rainfall and streamflow in the Milwaukee

43 River Basin to help better understand the influence of urbanization.

45 Streamflow (runoff) trends, in response to climate and/or human activity, have been

46 extensively investigated worldwide at various scales, and the literature is well summarized 
47 by Sahoo and Smith (2009). With respect to urbanization, which Dow and DeWalle (2000)

48 defined in hydrologic terms as the increase in impervious areas and the loss of vegetation,

49 the literature generally concludes that higher degrees of urbanization lead to higher mean

50 and extreme flows and shorter time to peaks in hydrographs (e.g. Watts and Hawke 2003;

51 Chang 2007; Choi and Deal 2008; Sheng and Wilson 2009; Bhaskar and Welty 2012;

52 Huang et al. 2012; Zhou et al. 2013). However, the effect of urbanization on the rainfall-

53 runoff relationship is not always obvious. A modeling study revealed a logistic relationship

54 between percent impervious cover and runoff ratio (fraction of runoff to precipitation) for

55 the Gwynns Falls Basin in Maryland (Brun and Band 2000). A data-driven study found

56 inconsistent trends in hydrological variables between urban and rural catchments of Maine

57 and attributed it to the low level of urbanization (Martin, Kelleher, and Wagener 2012).

59 There are a few widely adopted approaches in the literature about streamflow and

60 urbanization. One is to examine and compare long-term trends of streamflow between

61 catchments with different degrees of urbanization (e.g. Sahoo and Smith 2009; Martin,

62 Kelleher, and Wagener 2012; Velpuri and Senay 2013). The non-parametric Mann-Kendall

63 test for trend (Mann 1945; Kendall 1975) is frequently employed in this approach. This

64 approach provides insight into the stationarity and periodicity of the hydrological and

65 climatological variables, and allows one to determine whether these variables significantly

66 changed over time. Attributing the changes to particular causes, e.g. climatic and land cover

67 changes, is often done by examining inconsistencies between the variables or catchments

68 examined. Another approach is to run a hydrological model and examine the runoff 
69 characteristics and their changes (e.g. Choi and Deal 2008; Tu 2009; Huang et al. 2012;

70 Zhou et al. 2013). This approach enables one to control for other variables affecting the

71 rainfall-runoff relationship, but it is subject to modeling uncertainty. The other approach is

72 to compare runoff characteristics, such as runoff ratio, recession constant, and time to peak,

73 from observed data between catchments (e.g. Rose and Peters 2001; Watts and Hawke

74 2003; Chang 2007; Meierdiercks et al. 2010). Such studies generally found significant

75 differences between more and less urbanized catchments. The selection of study

76 catchments is very important when using this approach. The current study adopts both the

77 first and third approaches, considering the availability of streamflow data and different

78 degrees of urbanization across the Milwaukee River Basin.

80 An interest in long-term trends motivated the present study. Scientists have conducted little

81 research of this sort for streamflow in Wisconsin, even though rivers and streams are

82 among the state's most important natural resources (WDNR 2011). Existing research finds

83 that annual low flows increased significantly, whereas annual flood peaks decreased in

84 southwestern Wisconsin (Gebert and Krug 1996). Average annual streamflow and average

85 annual baseflow were found to show generally increasing trends across the state of

86 Wisconsin, and the Milwaukee River showed increasing trends in both variables significant

87 at the 5 percent level during 1915-1999 (Gebert et al. 2007). However, those studies did

88 not explicitly consider anthropogenic changes in land cover to explain the streamflow

89 trends. In addition, the Milwaukee River Basin is suitable for examining streamflow

90 characteristics between more and less urbanized catchments with at least a couple of 
91 decade's streamflow data. Therefore, the present study (1) analyzed long-term

92 temperature, precipitation, and streamflow data for selected catchments; (2) examined

93 rainfall-runoff relationships in relation to urban growth; and (3) compared streamflow

94 characteristics between catchments with different degrees of urbanization. This study not

95 only provides a detailed picture of the hydrology of the Milwaukee River Basin, but also

96 demonstrates the utility of a range of statistical methods for hydroclimatological analyses.

97

98

99 STUDY AREA

100

101 The study area is the Milwaukee River Basin located in southeastern Wisconsin, United

102 States (Figure 1). The areal extent is about $2330 \mathrm{~km}^{2}$, and it is home to about one million

103 people. The basin includes three primary rivers, Milwaukee, Menomonee, and

104 Kinnickinnic, which meet as they empty into Lake Michigan in the heart of downtown

105 Milwaukee. The estuary formed by this confluence of rivers is highly urbanized, and the

106 United States Environmental Protection Agency has listed it as an Area of Concern (US

107 EPA 2013). The topography of the area is comprised of rolling moraine over bedrock,

108 and slopes downward from the northwest to the southeast with a range of about 250

109 meters (WDNR 2001).

110

111 The southern portions of the basin are highly urbanized, whereas northern portions are

112 much less so, with land cover consisting primarily of agricultural land. The Milwaukee and 
113 Menomonee catchments drain both urban and rural communities, whereas the Kinnickinnic

114 catchment is almost entirely urbanized. Concrete lines the majority of the Kinnickinnic

115 River as a flood-control measure implemented in the 1960s.

118 DATA

119

120 The United States Geological Survey web site (USGS 2014) provided daily mean

121 streamflow data (measured in cubic feet per second) for the four sites listed in Table 1. Site

12204087000 MILWAUKEE RIVER AT MILWAUKEE, WI, is located just upstream of the

123 highly urbanized area in Milwaukee, and this station is short-named 'Milwaukee'. Site

12404086600 MILWAUKEE RIVER NEAR CEDARBURG, WI is located upstream of the 125 Milwaukee station, and its drainage area is mostly rural. This site is short-named

126 'Cedarburg'. Site 04087159 KINNICKINNIC RIVER@ @. 11TH STREET @

127 MILWAUKEE, WI (hereafter referred to as 'Kinnickinnic') has a small drainage area, and

128 is located in a densely developed area. Site 04087120 MENOMONEE RIVER AT

129 WAUWATOSA, WI (hereafter referred to as 'Menomonee') is located in a largely urban

130 drainage area. The unit of the streamflow data was converted to cubic meters per second.

131 When the flow data were aggregated to monthly and annual scales, the unit was converted

132 to millimeters by multiplying by the number of seconds and dividing by the catchment

133 area. It allows for direct comparisons to precipitation and between catchments and is 
134 referred to here as runoff, since runoff is defined as the part of precipitation that appears as 135 streamflow (WMO/UNESCO Panel on Terminology 1992).

137 Serbin and Kucharik (2009) developed gridded data sets of daily maximum and minimum 138 temperatures and precipitation data for Wisconsin. They developed the data sets by 139 interpolating weather station data across the state of Wisconsin for the period 1950-2006.

140 The grid spacing is about $8 \mathrm{~km}$. We downloaded the data from a server located at the 141 University of Wisconsin-Madison and clipped it for our study area (Figure 1). The data 142 points with different symbols correspond to each of the USGS sites. We used averaged data 143 from the grid points with the same symbol to compare to runoff data from the 144 corresponding USGS site. Note that the grid points for Cedarburg were also used for 145 Milwaukee.

146

147 Local land use data were obtained from the American Geographical Society Library at the 148 University of Wisconsin-Milwaukee. It was produced by the Southeastern Wisconsin 149 Regional Planning Commission in 2004 as an ArcGIS shapefile, and shows historic urban 150 growth inventory since the late $19^{\text {th }}$ century in southeastern Wisconsin counties every few

151 years up to year 2000 (Figure 2). The dataset does not include two counties that overlap 152 the northern edge of the basin. However, because there has been little urban growth in the 153 area, it is still usable for the study. 


\section{METHODS}

\section{Land use change anaysis}

160 The Wisconsin Department of Natural Resources divides the Milwaukee River Basin into 161 six catchments (WDNR 2001). Because streamflow data are applicable to the upstream 162 areas of the gauging sites, we further divided the catchments between upstream and

163 downstream parts of the gauging sites. We followed the general procedure to delineate

164 catchment boundaries using a digital elevation model obtained from the National Elevation

165 Dataset. Figure 1 shows the resulting boundaries. Land use data overlaid the catchment 166 boundaries and then clipped accordingly. Their statistics were aggregated for all 167 catchments upstream of each USGS site. This study did not analyze catchments 168 downstream of Milwaukee, Menomonee, and Kinnickinnic sites.

\section{Quantile regression}

172 The interannual variability of annual runoff was analyzed using quantile regression models 173 (Koenker 2005), with year as an explanatory variable and annual runoff as the dependent 174 variable. With quantile regression, it is possible to examine changes in specific parts 175 (quantiles) of the distribution of the data (Linares, Delagado-Huertas, and Carreira 2011). 176 The $\tau^{\text {th }}$ quantile $(0<\tau<1)$ represents the value of the data below which the proportion of 177 population is $\tau$. For example, the central location of a distribution is represented by the $0.5^{\text {th }}$ 
178 quantile (median), and the boundary between the top 5 percent and the rest is represented

179 by the $0.95^{\text {th }}$ quantile (Koenker 2005). In this study, we used the quantreg package 180 (Koenker 2012) add-on to the R language combined with MATLAB $\AA$ coding. It is 181 available upon request from the lead author.

182

\section{Extreme streamflow analysis}

185 To compare the catchments with respect to extreme streamflow, we calculated annual 186 maximum, $99^{\text {th }}$ and $95^{\text {th }}$ percentile flows. We calculated annual maximum flows by 187 choosing the maximum value of each year's daily mean streamflow. To make them 188 comparable between the catchments, we divided annual maximum flows by the catchment 189 area. We calculated annual $99^{\text {th }}$ and $95^{\text {th }}$ percentile flows in a similar way, by choosing the $19099^{\text {th }}$ and $95^{\text {th }}$ percentile values of each year's daily flow, respectively. To examine the

191 statistic with respect to the median and to allow for inter-catchment comparison, we divided 192 annual $99^{\text {th }}$ and $95^{\text {th }}$ percentile flows by annual median flows.

\section{Mann-Kendal test for trend}

196 This study analyzed the temporal trends of precipitation, runoff, and runoff ratio data using 197 the Mann-Kendall test for trend. For the Mann-Kendall test, we followed the procedure 198 laid out by Manly (2009, 192), as follows: 
199 For a data series $x_{n}$, the test statistic $S$ is the sum of the signs of the differences between

200 any pair of observations,

$201 \quad S=\sum_{i=2}^{n} \sum_{j=1}^{i-1} \operatorname{sign}\left(x_{i}-x_{j}\right)$

202 where $\operatorname{sign}(a)$ is -1 when $a$ is negative, 0 for zero, and 1 for positive. When the order of

203 the series is random, the expected value of $S$ is zero and the variance is:

$204 \operatorname{Var}(S)=n(n-1)(2 n+5) / 18$

$205 Z$ statistic tests whether $S$ is significantly different from zero, shown as follows:

if $S>0, Z=\frac{S-1}{\sqrt{V S}}$

206

else $Z=\frac{S+1}{\sqrt{V S}}$

$207 Z$ follows the standard normal distribution, and its significance can be compared with

208 critical values in the distribution. A positive $Z$ value indicates a positive trend and a

209 negative one indicates negative in a two-sided test. For monthly data, the statistics $S$ and

$210 \operatorname{Var}(S)$ were calculated for each month of the year and summed for an overall test to account

211 for seasonality (Manly 2009, 192).

212

\section{Double-mass curve}

214

215 Double-mass curves for each catchment provided the tool to create and evaluate the

216 relationship between precipitation and runoff over time. The double-mass curve method 
217 builds from the idea that there is a proportional relationship between two variables, in this

218 instance precipitation and runoff (Cluis 1983; Zhao et al. 2004; Kliment and

219 Matouskova 2008; Zhang and Lu 2009; Du et al. 2011). This proportional

220 relationship can be plotted as the cumulative value of one variable against the

221 cumulative value of the other, in which the slope of the line that they form represents

222 the relationship between the two (Searcy and Hardison 1960). Any change in

223 slope represents a change in the relationship between precipitation and runoff. This

224 method is useful for investigating the influence of anthropogenic changes upon the

225 relationship between precipitation and runoff.

226

227 We made double-mass curves for each of the four catchments by plotting the 228 cumulative annual runoff values (measured in $\mathrm{mm}$ ) to the cumulative annual

229 precipitation values (measured in $\mathrm{mm}$ ) of the area. Breaks in the slope of each curve were

230 identified and tested for statistical significance using an analysis of variance test 231 (ANOVA) as outlined in Searcy and Hardison (1960).

232

233

234 RESULTS AND DISCUSSION

235

236 Urban growth in the Milwaukee River Basin

237 
238 Figure 3 shows the fraction of developed area in each catchment. The fraction of developed

239 areas increased in all the catchments, particularly in Cedarburg which saw it more than

240 quadruple. However, it still remains very undeveloped, less than 12 percent in year 2000.

241 Kinnickinnic is the most urbanized catchment throughout the time measured but stays

242 almost flat since the 1980s. On the other hand, Milwaukee and Menomonee saw steady

243 growth. Because Cedarburg is nested in Milwaukee, the increase in Milwaukee is partly

244 due to the increase in Cedarburg.

246 Summary of temperature, precipitation, and runoff

248 Table 2 summarizes daily maximum temperature (TMAX), minimum temperature

249 (TMIN), precipitation (PRCP) for the period 1950-2006, and runoff for the time periods

250 for which each catchment's data were obtained. Temperatures are almost identical between

251 the catchments. Precipitation statistics are very similar between Milwaukee, Cedarburg,

252 and Menomonee, whereas Kinnickinnic shows somewhat larger mean and standard

253 deviation of annual precipitation. Kinnickinnic and Menomonee, more urbanized

254 catchments than the others, show the largest mean annual runoff during the available data

255 periods. Interestingly, more-urbanized Milwaukee has lower annual mean and monthly

256 maxima of runoff and smaller variability than Cedarburg.

258 Figure 4 portrays interannual variability in annual total runoff. Milwaukee's annual runoff 259 (Figure 4A) was relatively low in the 1930s through 1960s and high since then, both for 
260 the middle $(\tau=0.5)$ and high $(\tau=0.9)$ ends of the data. Runoff $(\tau=0.5)$ in the $2000 \mathrm{~s}$ is

261 significantly higher than that in the 1940s, indicated by the non-overlapping confidence

262 intervals. The $0.9^{\text {th }}$ quantile annual runoff also tends to increase since the $1940 \mathrm{~s}$, but the

263 confidence intervals overlap. The annual runoff for Cedarburg (Figure 4B) shows a U-

264 shaped trend both for the middle and high ends of the data, with a trough in the late 1990s.

265 Annual runoff for Menomonee increased overall (Figure 4C). It appears to have reached a

266 plateau in the 1990s, both for the middle and high ends of the data. The increasing-then-

267 leveling trend is largely because the measurement began in the 1960s when runoff was low.

268 Runoff in 2008 was particularly high, when a large swath of the state was flooded in June.

269 This is similar in other catchments. The increase in the middle end of the data is significant,

270 but that in the high end is not. Kinnickinnic (Figure 4D) shows no particular trend in annual

271 runoff during the data period, but an increasing variability since the late 1990s. At the same

272 time, it monotonically increased from 1996 to 1999, and then decreased through 2003. Both

273 minimum and maximum runoff values occurred in the $21^{\text {st }}$ century.

275 Extreme streamflow

276

277 The annual maximum of daily mean flow was compared between the catchments for 1983-

278 2008. For comparison, streamflow values were divided by the catchment area. Not 279 surprisingly, it is highest in Kinnickinnic, followed by Menomonee (Figure 5). Those of 280 Milwaukee and Cedarburg are mostly the same. When it comes to temporal trend, none of 281 the catchments show any significant trends during that time. It could be because the time 
282 period was too short for urbanization effects to appear, or precipitation patterns held back

283 the annual maximum flow. During 1950-2006, most of the extreme precipitation indices

284 examined by Choi et al. (2013) show no statistically significant increases in much of the

285 study area.

287 The ratio of annual $99^{\text {th }}$ percentile flow to annual median flow (Figure 6) shows similar 288 inter-catchment differences to the annual maximum of daily mean flow, i.e. lower in 289 Milwaukee and Cedarburg and higher in Menomonee and Kinnickinnic. Assuming that the 290 precipitation characteristics are practically identical between the catchments, the higher 291 ratios suggest larger effects of urban land cover. Interestingly, the ratio of annual $99^{\text {th }}$ 292 percentile to median appears to be increasing in the two highly urbanized basins, whereas

293 the annual maximum of daily mean flow did not reveal significant trends. Increasing ratios 294 suggest that daily streamflow became more extreme, likely either due to extreme rainfall 295 events or high degrees of urbanization, which was not identified from the annual maximum 296 of daily mean flow. The annual maximum of daily mean flow reflects the flow condition 297 of a particular day, whereas the ratio of annual $99^{\text {th }}$ percentile to median reflects an extreme 298 flow condition with respect to a normal condition. Therefore, the ratio better reflects the 299 changes in streamflow characteristics than the annual maximum. The ratio of annual $95^{\text {th }}$ 300 percentile flow to annual median flow shows similar trends to those shown in Figure 6, 301 therefore this this article omits them. 


\section{Relationship between precipitation and runoff}

305 Precipitation and runoff generally changed in the same directions but with different

306 strengths (Table 3). Overall, monthly data show stronger trends than annual data. In

307 Milwaukee, monthly precipitation did not increase significantly but runoff did, and

308 monthly runoff ratio increased significantly during 1950-2006. Because runoff increased

309 significantly whereas precipitation did not, it can be speculated that runoff changes are

310 largely due to human causes, such as increased imperviousness of the catchment (Velpuri

311 and Senay 2013). It should be noted that base flow increased in Milwaukee during 1970-

3121999 (Gebert et al. 2007), also contributing to the runoff increase. Menomonee also shows

313 a significant increase in runoff ratio, as well as in precipitation and runoff during 1962-

314 2006. It indicates that runoff increased more than what is expected from the precipitation

315 increase, thus both anthropogenic and climatic factors played a role. On the other hand,

316 Cedarburg and Kinnickinnic showed decreases in both precipitation and runoff since the

317 early 1980s, although only Cedarburg monthly runoff decreased significantly. Cedarburg

318 shows a significant decrease in runoff ratio, suggesting an anthropogenic factor reducing

319 runoff. Kinnickinnic had been heavily developed by the 1980 s, therefore it is speculated

320 that additional development did not result in any significant runoff changes.

321

322 Figure 7 shows the double-mass curve for each basin considered in the study. Three of

323 the catchments exhibit a break in slope that is statistically significant. One catchment, 324 Kinnickinnic, does not possess breaks in slope that are statistically significant, although 
325 it does appear to have a slight change in slope during the time from 1994 to 1996. Cluis

326 (1983) warns against considering any period of time less than five years as a distinct

327 period of change in the runoff regime due to the variability inherent in hydrological

328 systems. Although the breaks in slope for the Kinnickinnic are not significant, they were

329 included in the double-mass curve figure for consideration by the reader. It also should be

330 noted that the slope changed in Cedarburg only after five years, which is quite short

331 compared to other catchments.

332

333 The three remaining catchments illustrate some interesting trends. Both Menomonee and

334 Milwaukee exhibit a statistically significant break in slope in the early 1970s, with $p$ -

335 values not exceeding 0.001. In both cases, the slope increased following the break.

336 Before the break point, precipitation was generally below the mean, and it was

337 generally above the mean afterwards. Coinciding with urban growth, runoff ratio

338 generally increased in the two catchments (Table 3), and the double curve slope is

339 steeper than before. Therefore, the break point in the early 1970s is thought to be

340 mainly a result of precipitation trend rather than faster urban growth afterwards.

341 Kinnickinnic, even though insignificant, also shows an increasing slope in recent years.

342 Interestingly, the slope change in Cedarburg does not match those of the other

343 catchments. Cedarburg shows a statistically significant break in slope $(p=0.002)$ around

344 the year 1986. Prior to 1986 , the slope of the curve was 0.357 , but it decreased to 0.285

345 following the break, in line with the runoff ratio decrease (Table 3). The reason why

346 it decreased could not be found, but it is speculated that the short (5 
347 years) period before the break point could be a reason. The year 1986 is

348 a break point of annual precipitation in Cedarburg during the time span

349 of 1982-2006, before which annual precipitation was generally above the

350 mean and after which below the mean. The steeper slope of the double

351 mass curve before 1986 occurred during the short wet period and may be

352 seen as an aberration. It should be also noted that Cedarburg is still

353 fairly rural, and signs of urbanization impacts may not be visible yet, as

354 in the case of Martin, Kelleher, and Wagener (2012).

\section{CONCLUSIONS}

359 Climatic and land cover conditions strongly influence the rainfall-runoff relationship of a

360 catchment. At the same time, they do not remain constant either over time. In this study,

361 using the Milwaukee River Basin as a study site, we analyzed land use changes in the basin

362 and the trends of temperature, precipitation, and streamflow statistics for the four selected

363 catchments with varying degrees of urbanization. Then we examined how rainfall-runoff

364 relationships differed between the catchments using double mass curves. Our findings

365 include the following: (1) urban land use in the Milwaukee River Basin as a whole

366 increased substantially during the last few decades; (2) the rainfall-runoff relationships

367 differed between the catchments mostly in line with the literature. In other words, more

368 urbanized ones showed higher mean and extreme runoff than less urbanized ones; (3) 
369 runoff ratio significantly increased, meaning runoff increased more than expected from

370 precipitation increases, in two catchments that have streamflow data for more than forty 371 years.

372

373 Overall, it was clear that more urbanized catchments had higher mean and extreme runoff

374 values, which can be regarded as the effects of urban land cover. However, effects of land

375 use change were not as clear, and only basins with long-term data showed increasing runoff

376 trends more than expected from increasing precipitation. One of the limitations of the study

377 is that it could not examine long-term data for an undeveloped catchment within the

378 Milwaukee River Basin because of lack of data. A well-calibrated hydrological model

379 could help overcome the limitation.

380

381

382 


\section{REFERENCES}

385 Bhaskar, A. S., and Claire W. 2012. Water balances along an urban-to-rural gradient of 386 metropolitan Baltimore, 2001-2009. Environmental \& Engineering Geoscience 18 $387 \quad(1): 37-50$.

388 Brun, S. E., and L. E. Band. 2000. Simulating runoff behavior in an urbanizing 389 watershed. Computers, Environment and Urban Systems 24: 5-22.

390 Chang, H. 2007. Comparative streamflow characteristics in urbanizing basins in the 391 Portland metropolitan area, Oregon, USA. Hydrological Processes 21 : 211-22.

392 Choi, W., R. Tareghian, J. Choi, and C.-s. Hwang. 2013. Geographically heterogeneous 393 temporal trends of extreme precipitation in Wisconsin, USA during 1950-2006.

394 International Journal of Climatology, DOI: 10.1002/joc.3878

395 Choi, W., and B. M. Deal. 2008. Assessing hydrological impact of potential land use 396 change through hydrological and land use change modeling for the Kishwaukee river basin (USA). Journal of Environmental Management, 88 (4): 1119-30.

398 Claessens, L., C. Hopkinson, E. Rastetter, and J. Vallino. 2006. Effect of historical

399 changes in land use and climate on the water budget of an urbanizing watershed.

$400 \quad$ Water Resources Research 42 (3): W03426.

401 Cluis, D. A. 1983. Visual techniques for the detection of water quality trends: Double402 mass curves and cusum functions. Environmental Monitoring and Assessment 3 (2): $403 \quad 173-84$. 
404 Dow, C. L., and D. R. DeWalle. 2000. Trends in evaporation and Bowen ratio on

405 urbanizing watersheds in eastern United States. Water Resources Research 36: 1835-

$406 \quad 43$.

407 Du, J., F. He, Z. Zhang, and P. Shi. 2011. Precipitation change and human impacts on

408 hydrologic variables in Zhengshui river basin, China. Stochastic Environmental

$409 \quad$ Research and Risk Assessment 25 (7): 1013-25.

410 Elsner, J. B., W. H. Drag, and J. K. Last. 1989. Synoptic weather patterns associated with

411 the Milwaukee, Wisconsin flash-flood of 6 August 1986. Weather and Forecasting 4

$412 \quad$ (4): $537-54$.

413 Federal Emergency Management Agency. 2010. President Declares Individual Assistance

414 for Grant and Milwaukee Counties. http://www.fema.gov/news-

415 release/2010/09/18/president-declares-individual-assistance-grant-and-milwaukee-

416 counties (last accessed 17 June 2014).

417 Gebert, W. A., and W. R. Krug. 1996. Streamflow trends in Wisconsin's driftless area.

$418 \quad$ Water Resources Bulletin 32 (4): 733-44.

419 Gebert, W. A., M. J. Radloff, E. J. Considine, and J. L. Kennedy. 2007. Use of

420 streamflow data to estimate base flow/ground-water recharge for Wisconsin. Journal

421 of the American Water Resources Association 43 (1): 220-36.

422 Hejazi, M. I., and M. Markus. 2009. Impacts of urbanization and climate variability on

423 floods in northeastern Illinois. Journal of Hydrologic Engineering 14 (6): 606-16.

424 Homer, C. H., J. A. Fry, and C. A. Barnes. 2012. The National Land Cover Database.

425 U.S. Geological Survey, U.S. Geological Survey Fact Sheet 2012-3020. 
426 Huang, S.-Y., S.-J. Cheng, J.-C. Wen, and J.-H. Lee. 2012. Identifying hydrograph

427 parameters and their relationships to urbanization variables. Hydrological Sciences

$428 \quad$ Journal-Journal Des Sciences Hydrologiques 57 (1): 144-61.

429 Kendall, M. G. 1975. Rank Correlation Methods. London, UK: Griffin.

430 Kliment, Z., and M. Matouskova. 2008. Long-term trends of rainfall and runoff regime in $431 \quad$ Upper Otava River Basin. Soil \& Water Research 3 (3): 155-67.

432 Koenker, R. 2005. Quantile Regression. Econometric society monographs. Cambridge,

$433 \quad$ UK; New York: Cambridge University Press.

434 Koenker, R. 2012. Quantile Regression and Related Methods. Available from

$435 \quad$ http://cran.r-project.org/web/packages/quantreg/index.html.

436 Linares, J. C., A. Delgado-Huertas, and J. A. Carreira. 2011. Climatic trends and different

437 drought adaptive capacity and vulnerability in a mixed abies pinsapo-pinus

438 halepensis forest. Climatic Change 105 (1-2): 67-90.

439 Manly, B. F. J. 2009. Statistics for Environmental Science and Management. Boca Raton:

$440 \quad$ CRC Press.

441 Mann, H. B. 1945. Nonparametric tests against trend. Econometrica 13: 245-59.

442 Martin, E. H., C. Kelleher, and T. Wagener. 2012. Has urbanization changed ecological

443 streamflow characteristics in Maine (USA)? Hydrological Sciences Journal-Journal

444 Des Sciences Hydrologiques 57 (7). DOI: 10.1080/02626667.2012.707318

445 MATLAB, R2011a, MathWorks, Natick, MA, United States 
446 Meierdiercks, K. L., J. A. Smith, M. L. Baeck, and A. J. Miller. 2010. Heterogeneity of

447 hydrologic response in urban watersheds. Journal of the American Water Resources

$448 \quad$ Association 46 (6): 1221-37.

449 Rose, S., and N. E. Peters. 2001. Effects of urbanization on streamflow in the Atlanta

450 area (Georgia, USA): A comparative hydrological approach. Hydrological Processes $451 \quad 15(8): 1441-57$.

452 Sahoo, D., and P. K. Smith. 2009. Hydroclimatic trend detection in a rapidly urbanizing 453 semi-arid and coastal river basin. Journal of Hydrology 367 (3-4): 217-27.

454 Searcy, J. R., and C. H. Hardison. 1960. Double-mass Curves. Washington, DC: United 455 States Government Printing Office, Geological Survey Water-Supply Paper 1541-B. 456 Sen, P. K. 1968. Estimates of the regression coefficient based on Kendall's tau. Journal 457 of the American Statistical Association 63: 1379-89.

458 Serbin, S. P., and C. J. Kucharik. 2009. Spatiotemporal mapping of temperature and 459 precipitation for the development of a multidecadal climatic dataset for Wisconsin. $460 \quad$ Journal of Applied Meteorology and Climatology 48 (4): 742-57.

461 Sheng, J., and J. P. Wilson. 2009. Watershed urbanization and changing flood behavior 462 across the Los Angeles metropolitan region. Natural Hazards 48 (1): 41-57.

463 Tu, J. 2009. Combined impact of climate and land use changes on streamflow and water 464 quality in eastern Massachusetts, USA. Journal of Hydrology 379: 268-283

465 United States Environmental Protection Agency. 2013. Great Lake Areas of Concern. 466 http://www.epa.gov/glnpo/aoc/milwaukee/index.html (last accessed 6 May 2014) 
467 United States Geological Survey. 2014. USGS Water Data for the Nation.

468 http://waterdata.usgs.gov/nwis (last accessed 6 May 2014)

469 Velpuri, N. M., and G. B. Senay. 2013. Analysis of long-term trends (1950-2009) in

470 precipitation, runoff and runoff coefficient in major urban watersheds in the United

$471 \quad$ States. Environmental Research Letters 8 (2): 024020.

472 Watts, L. F., and R. M. Hawke. 2003. The effects of urbanisation on hydrologic response:

473 A study of two coastal catchments. Journal of Hydrology (Wellington North) 42 (2):

$474 \quad 125-43$.

475 Wisconsin Department of Natural Resources. 2001. The State of the Milwaukee River

476 Basin. PUBL WT 704 2001. http://dnr.wi.gov/water/basin/milw/milwaukee_801.pdf

$477 \quad$ (last accessed 17 June 2014).

478 . 2011. Wisconsin Rivers. http://dnr.wi.gov/org/water/rivers/ (last accessed 24

$479 \quad$ March 2011).

480 WMO/UNESCO Panel on Terminology. 1992. International Glossary of Hydrology, $481 \quad$ WMO/OMM/BMO.

482 Zhang, S., and X. X. Lu. 2009. Hydrological responses to precipitation variation and 483 diverse human activities in a mountainous tributary of the lower Xijiang, China. $484 \quad$ Catena 77 (2): 130-42.

485 Zhang, Y., and J. A. Smith. 2003. Space-time variability of rainfall and extreme flood 486 response in the Menomonee river basin, Wisconsin. Journal of Hydrometeorology 4 487 (3): 506-17. 
488 Zhao, W. W., B. J. Fu, O. H. Meng, Q. J. Zhang, and Y. H. Zhang. 2004. Effects of land489 use pattern change on rainfall-runoff and runoff-sediment relations: A case study in 490 Zichang watershed of the loess plateau of China. Journal of Environmental Sciences$491 \quad$ China $16(3): 436-42$.

492 Zhou, F., Y. Xu, Y. Chen, C.-Y. Xu, Y. Gao, and J. Du. 2013. Hydrological response to 493 urbanization at different spatio-temporal scales simulated by coupling of CLUE-S 494 and the SWAT model in the Yangtze river delta region. Journal of Hydrology 485:

$495 \quad 113-25$.

496

497 
498

499

\begin{tabular}{|c|c|c|c|c|c|}
\hline Site number & Short name & $\begin{array}{l}\text { Latitude }(\mathbf{N}) \text {, } \\
\text { longitude } \\
(\mathrm{W})\end{array}$ & $\begin{array}{l}\text { Elevation } \\
\text { above } \\
\text { sea level }\end{array}$ & $\begin{array}{l}\text { Drainage } \\
\text { area }\end{array}$ & $\begin{array}{l}\text { Record } \\
\text { obtained } \\
\text { for the } \\
\text { period }\end{array}$ \\
\hline 04087000 & Milwaukee & $\begin{array}{l}43^{\circ} 06^{\prime} 00^{\prime \prime}, \\
87^{\circ} 54^{\prime} 32^{\prime \prime}\end{array}$ & $184.99 \mathrm{~m}$ & $\begin{array}{l}1802.63 \\
\mathrm{~km}^{2}\end{array}$ & $1915-2008$ \\
\hline 04086600 & Cedarburg & $\begin{array}{l}43^{\circ} 16^{\prime} 49^{\prime \prime}, \\
87^{\circ} 56^{\prime} 30^{\prime \prime}\end{array}$ & $199.14 \mathrm{~m}$ & $\begin{array}{l}1572.12 \\
\mathrm{~km}^{2}\end{array}$ & $1982-2008$ \\
\hline 04087159 & Kinnickinnic & $\begin{array}{l}42^{\circ} 59^{\prime} 51^{\prime \prime}, \\
87^{\circ} 55^{\prime} 35^{\prime \prime}\end{array}$ & $179.39 \mathrm{~m}$ & $\begin{array}{l}48.69 \\
\mathrm{~km}^{2}\end{array}$ & $1983-2008$ \\
\hline 04087120 & Menomonee & $\begin{array}{l}43^{\circ} 02^{\prime} 44^{\prime \prime}, \\
87^{\circ} 59^{\prime} 59^{\prime \prime}\end{array}$ & $191.59 \mathrm{~m}$ & $\begin{array}{l}318.57 \\
\mathrm{~km}^{2}\end{array}$ & $1962-2008$ \\
\hline
\end{tabular}

Table 1. United States Geological Survey sites selected for streamflow data 
502 Table 2. Statistics of TMAX, TMIN, PRCP, and runoff by catchment. Climate variables are for 1950-

5032006 and runoff is for the available data period as shown in Table 1.

\begin{tabular}{|c|c|c|c|c|}
\hline & Milwaukee & Cedarburg & Menomonee & Kinnickinnic \\
\hline Average TMAX $\left({ }^{\circ} \mathrm{C}\right)$ & 13.3 & 13.2 & 13.6 & 13.3 \\
\hline Average TMIN $\left({ }^{\circ} \mathrm{C}\right)$ & 2.7 & 2.6 & 2.9 & 3.5 \\
\hline Annual PRCP (mm) & 808 & 807 & 807 & 841 \\
\hline $\begin{array}{l}\text { Standard deviation, annual } \\
\text { PRCP }\end{array}$ & 117 & 116 & 127 & 152 \\
\hline $\begin{array}{l}\text { Maximum single-month } \\
\text { PRCP (mm) }\end{array}$ & 285 & 294 & 283 & 288 \\
\hline $\begin{array}{l}\text { Minimum single-month PRCP } \\
(\mathrm{mm})\end{array}$ & 1.5 & 1.6 & 0.2 & 0.6 \\
\hline Mean annual runoff $(\mathrm{mm})$ & 219 & 257 & 300 & 461 \\
\hline Standard deviation & 83.5 & 103.7 & 99.8 & 103.7 \\
\hline $\begin{array}{l}\text { Maximum single-month } \\
\text { runoff }(\mathbf{m m})\end{array}$ & 149 & 210 & 186 & 210 \\
\hline $\begin{array}{l}\text { Minimum single-month runoff } \\
(\mathrm{mm})\end{array}$ & 0.8 & 5.9 & 0.9 & 5.8 \\
\hline
\end{tabular}


Table 3. Trends of annual (upper) and monthly (lower) PRCP, runoff, and runoff ratio from the Mann-

508 Kendall test by catchment.

\begin{tabular}{|l|l|l|l|l|l|l|}
\hline & PRCP & & Runoff & & $\begin{array}{l}\text { Runoff } \\
\text { ratio }\end{array}$ & \\
\hline & $\mathrm{p}$ & Sign & $\mathrm{p}$ & Sign & $\mathrm{p}$ & Sign \\
\hline Milwaukee & 0.06 & + & 0.05 & + & 0.26 & + \\
\hline Cedarburg & 0.44 & - & 0.09 & - & $\mathbf{0 . 0 3}$ & - \\
\hline Menomonee & $\mathbf{0 . 0 1}$ & + & $\mathbf{0 . 0 0}$ & + & 0.11 & + \\
\hline Kinnickinnic & 0.16 & - & 0.44 & - & 0.50 & + \\
\hline
\end{tabular}

\begin{tabular}{|l|l|l|l|l|l|l|}
\hline Milwaukee & 0.14 & + & $\mathbf{0 . 0 0}$ & + & $\mathbf{0 . 0 0}$ & + \\
\hline Cedarburg & 0.20 & - & $\mathbf{0 . 0 0}$ & - & $\mathbf{0 . 0 0}$ & - \\
\hline Menomonee & $\mathbf{0 . 0 2}$ & + & $\mathbf{0 . 0 0}$ & + & $\mathbf{0 . 0 0}$ & + \\
\hline Kinnickinnic & 0.24 & - & 0.20 & - & 0.91 & + \\
\hline
\end{tabular}

509 The bold fonts indicate that the trends are statistically significant $(\alpha=0.05)$ 


\section{FIGURES}

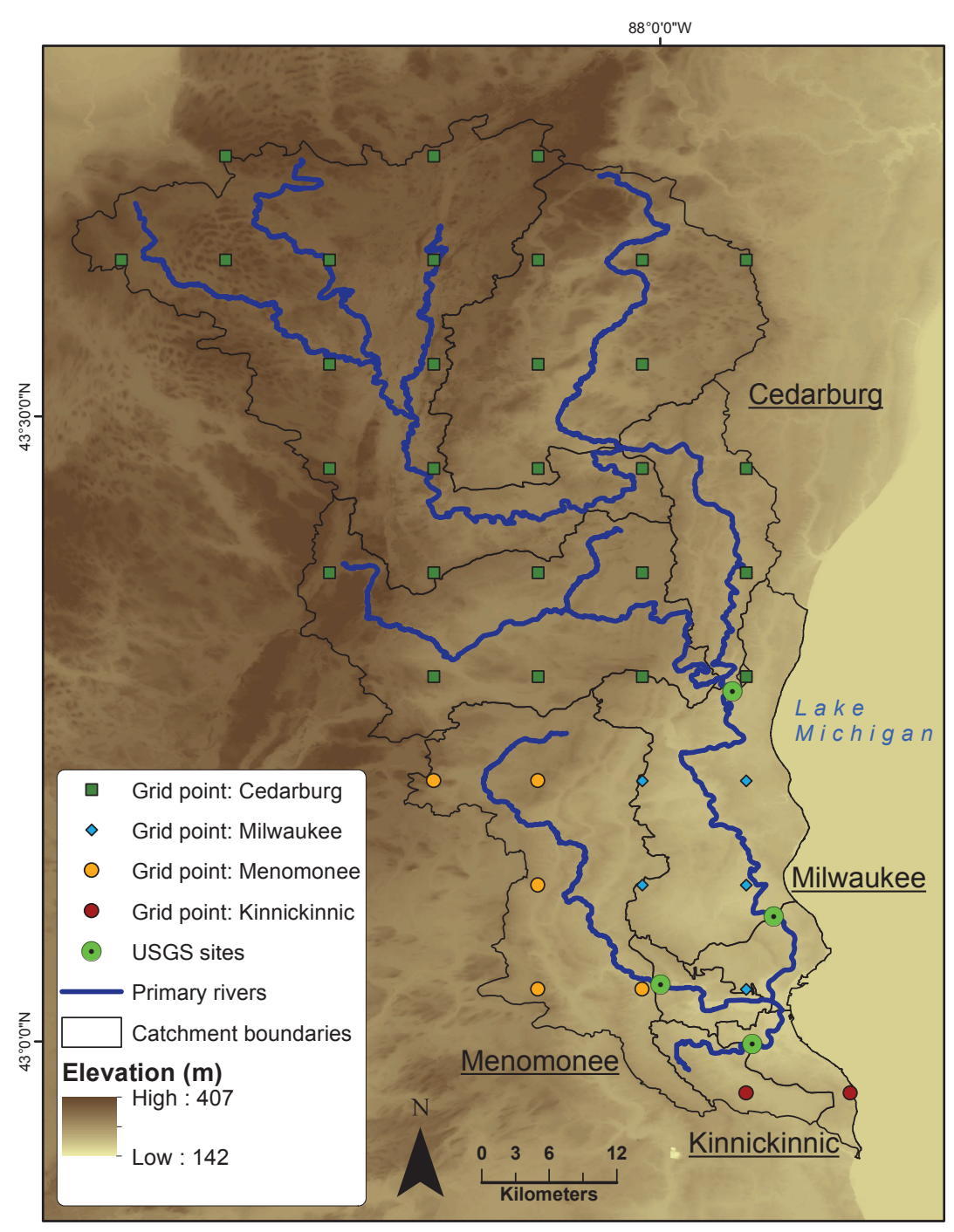

514

515 Figure 1. Landforms in the study area and locations of streamflow and climate data sources.

516 Larger green circles with a dot in them are United States Geological Survey streamflow

517 gages, and other symbols (circles, squares, and diamonds) indicate the grid points of the

518 climate data for each catchment 


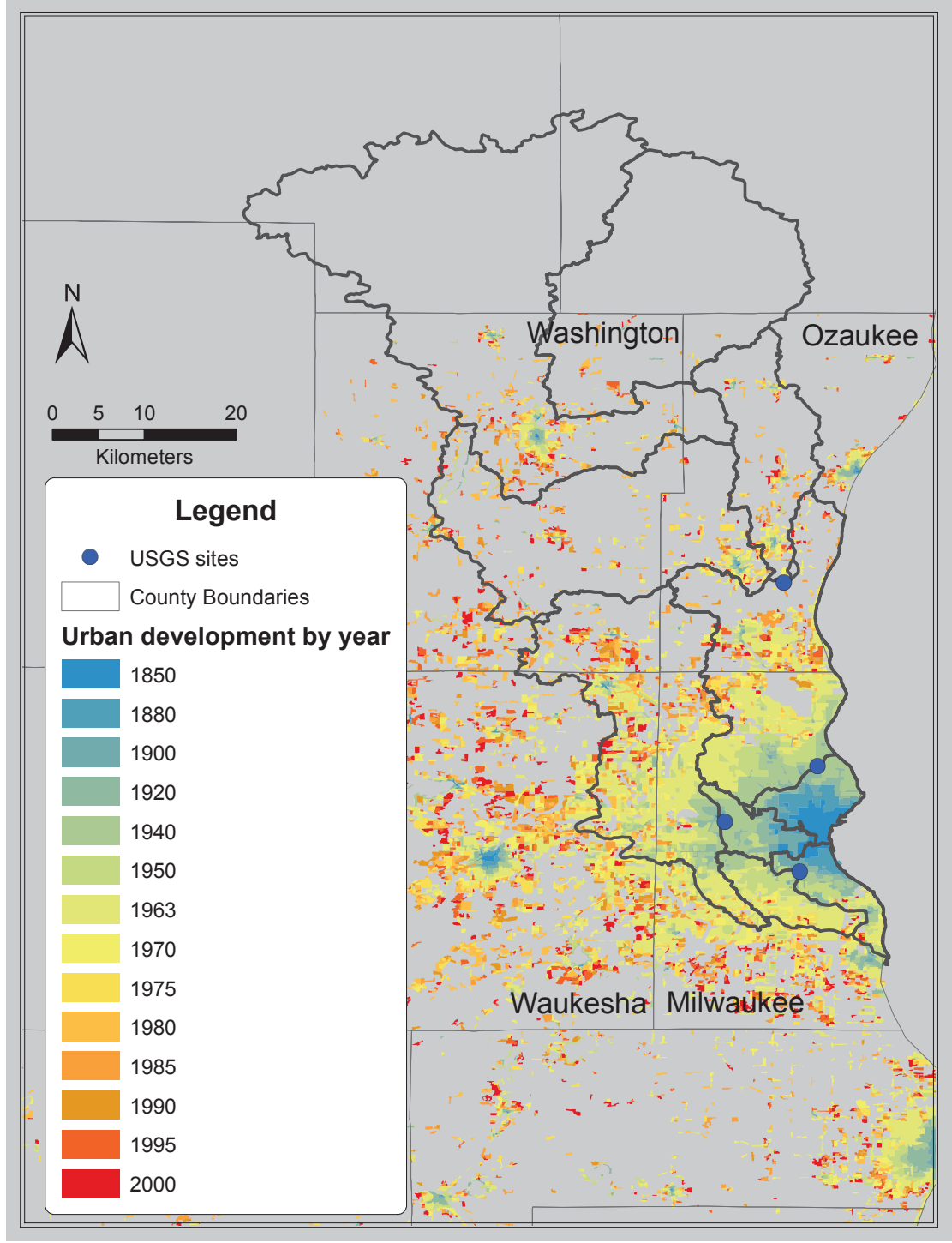

520 Figure 2. Expansion of developed areas (blue to red for older to newer) in southeastern

521 Wisconsin since the late $19^{\text {th }}$ century (data courtesy of Southeastern Wisconsin Regional

522 Planning Commission) 


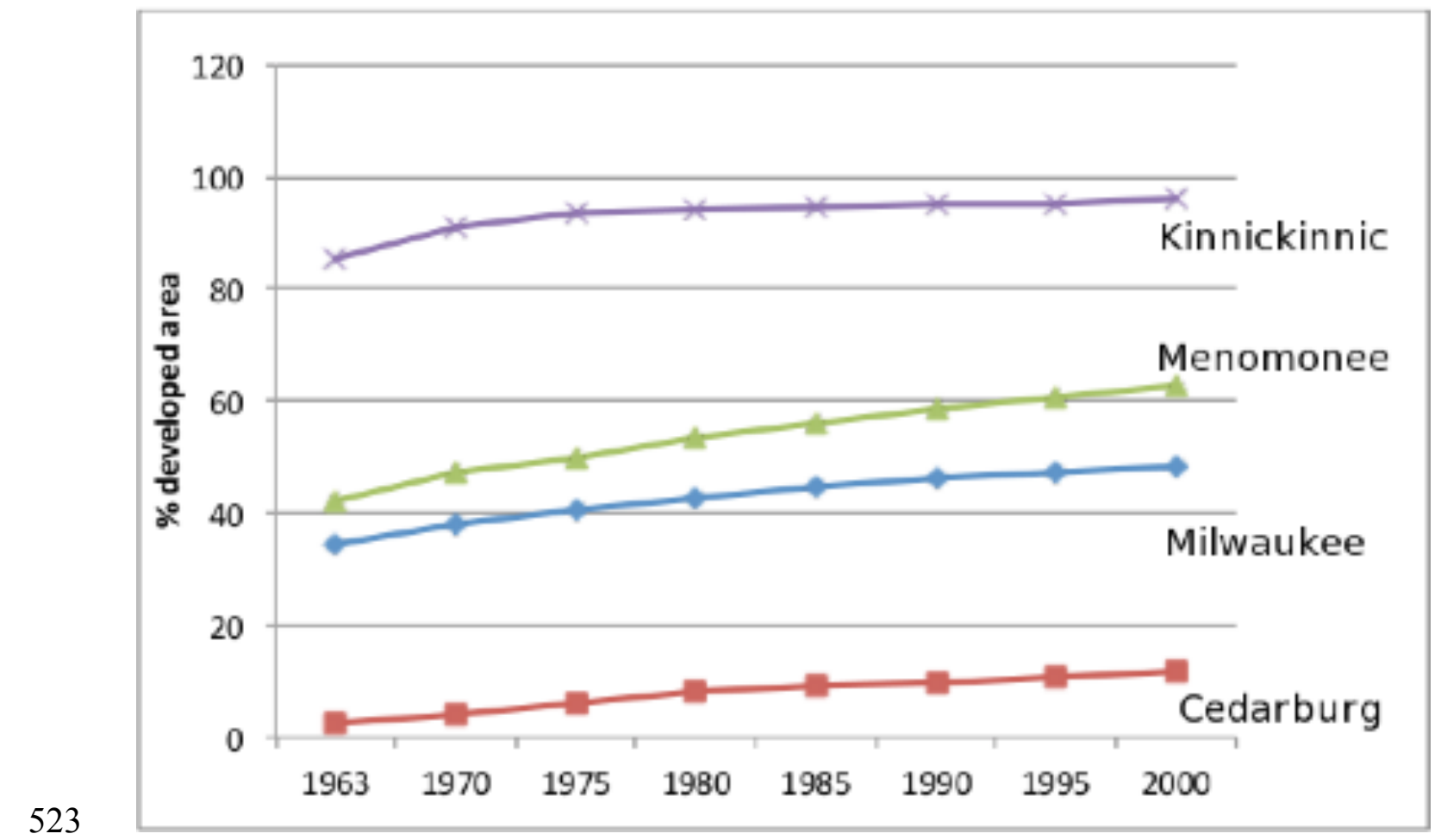

524 Figure 3. Fraction of developed areas for the four catchments calculated using the 525 Southeastern Wisconsin Regional Planning Commission data 526 
(A)

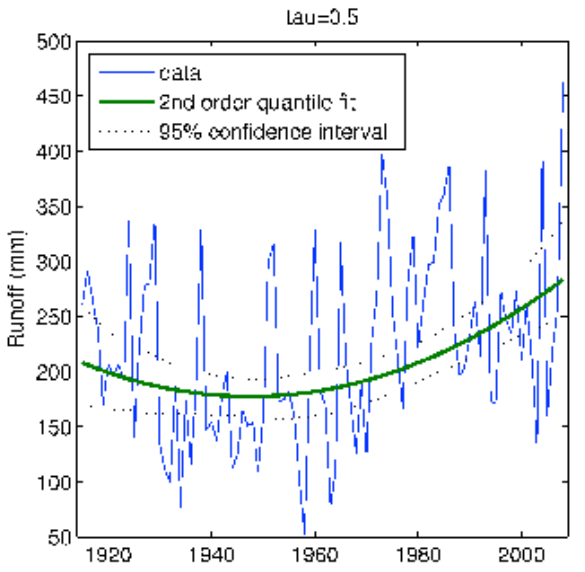

(B)

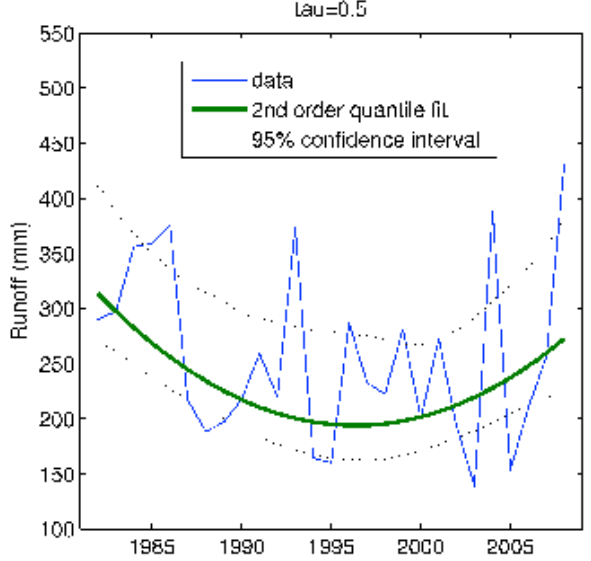

528

(c)

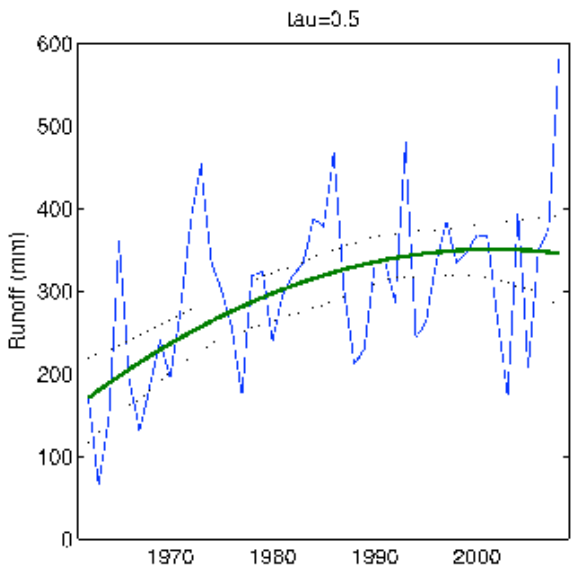

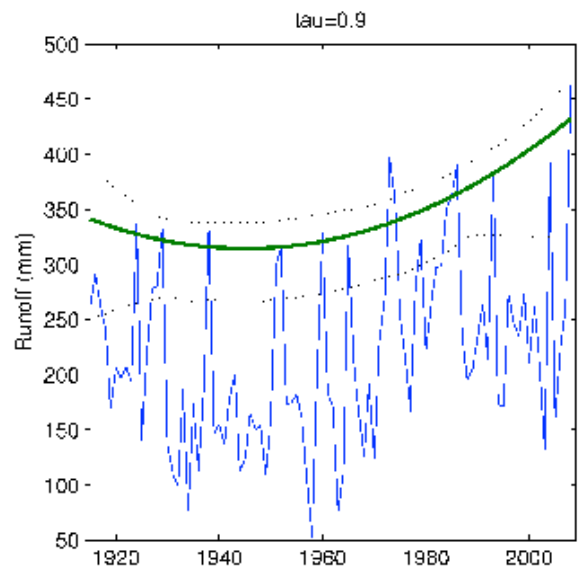
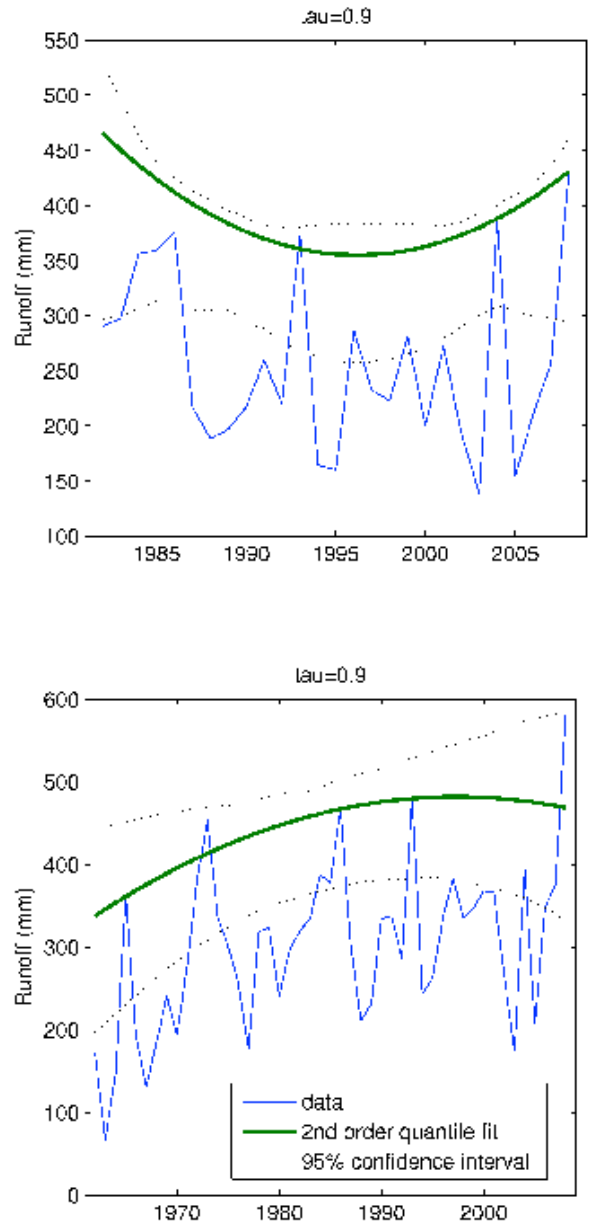
(D)

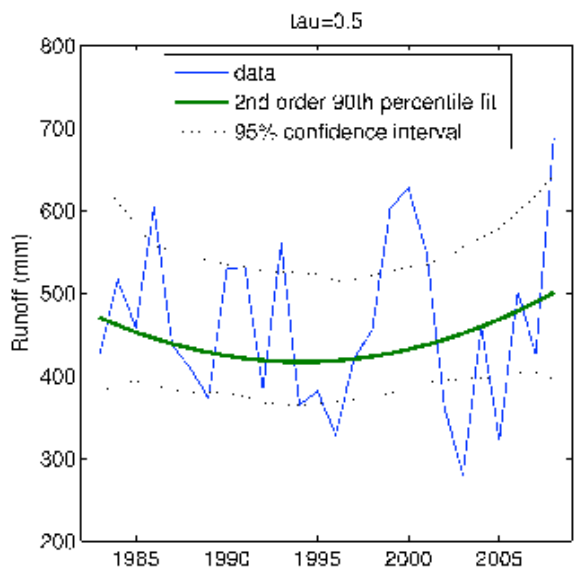

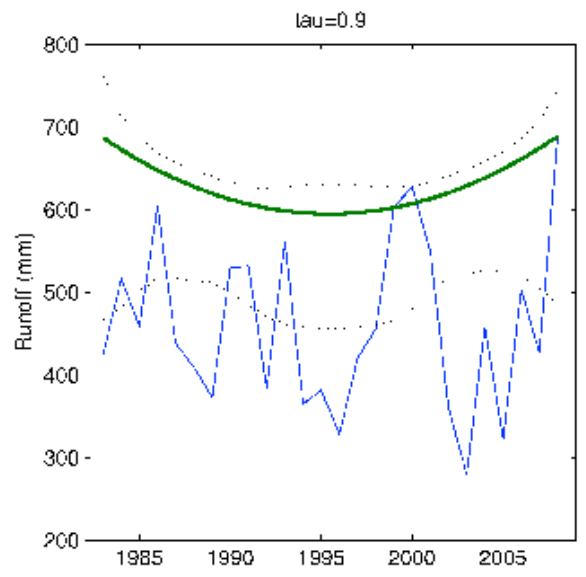

530

531 Figure 4. Annual runoff (thin blue line) with second order quantile regression lines (thick

532 green line) for (A) Milwaukee, (B) Cedarburg, (C) Menomonee, and (D) Kinnickinnic. The

533 left panel is for tau $=0.5$ and the right for tau $=0.9$ for the same annual runoff data. 


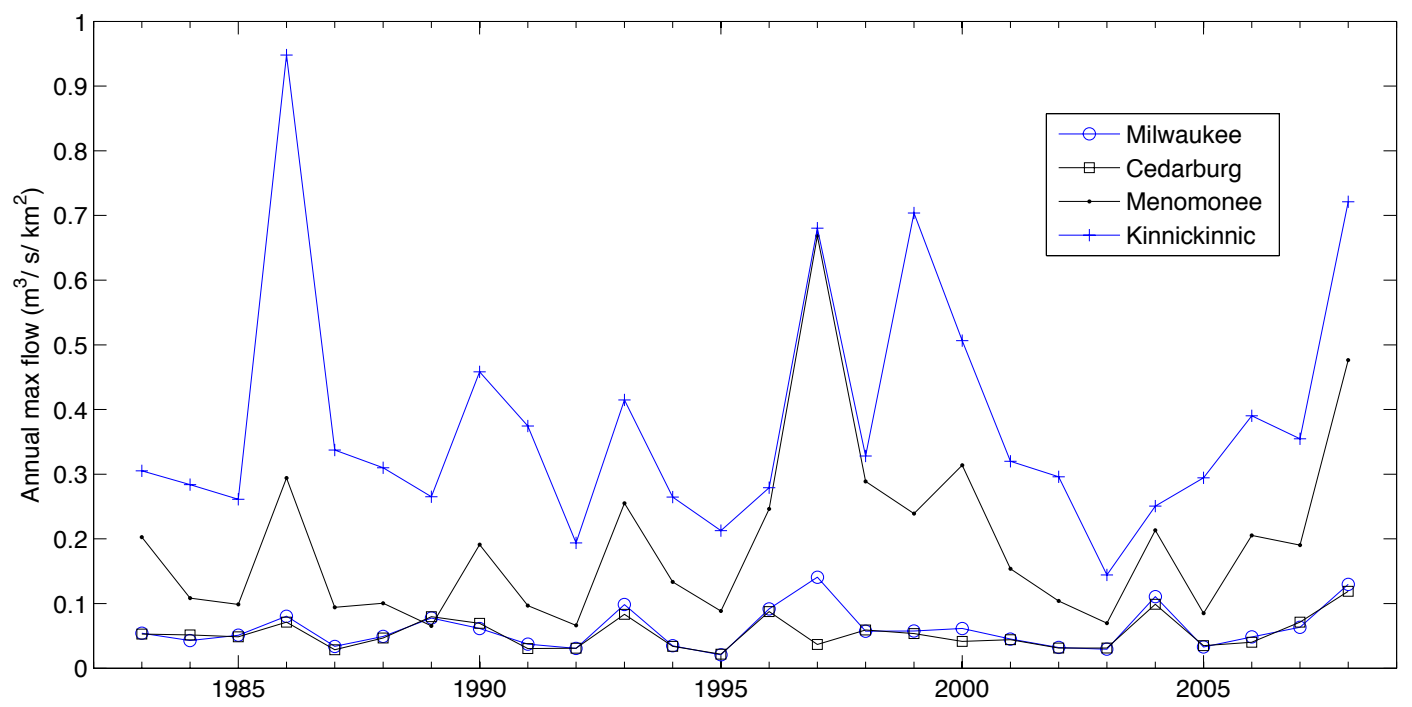

535

536 Figure 5. Annual maximum of daily mean streamflow during 1983-2008, divided by the

537 catchment area for comparison between the catchments 


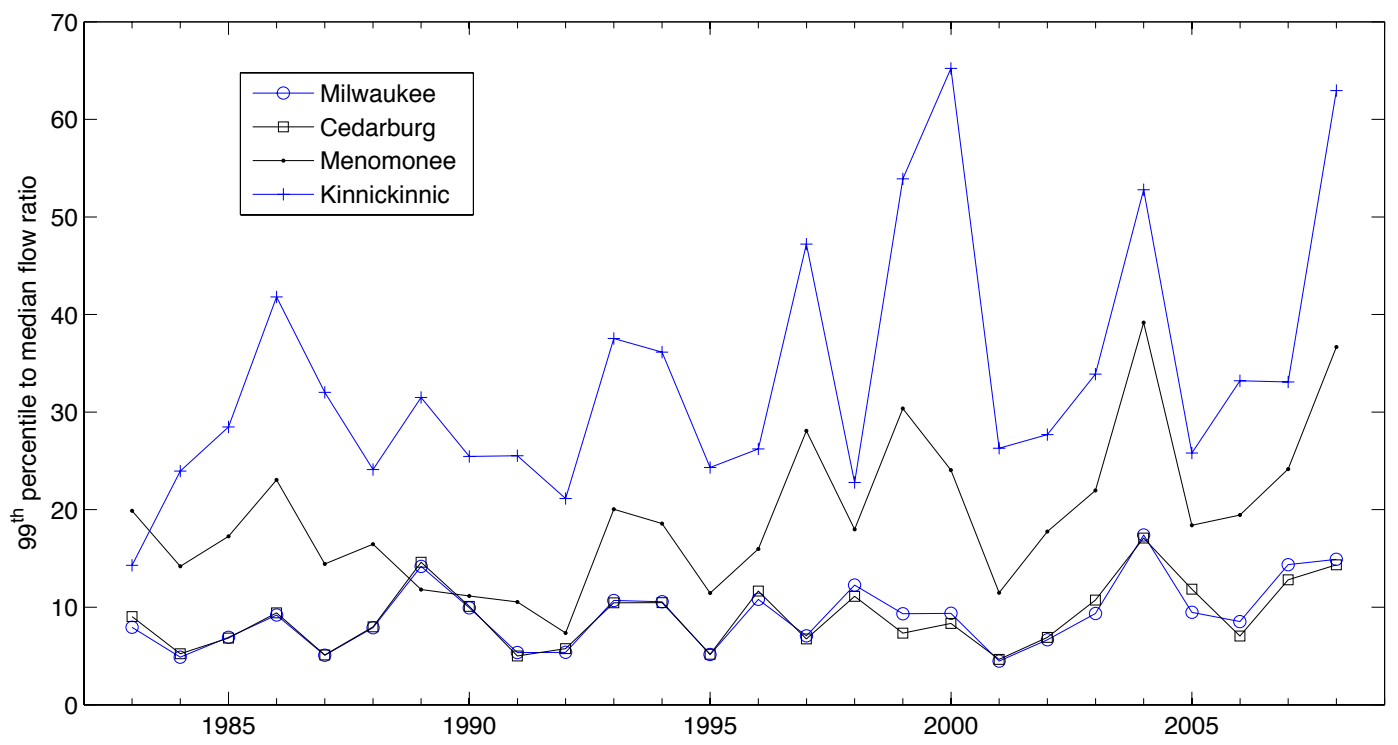

540

541 Figure 6 . Ratio of annual $99^{\text {th }}$ percentile flow to annual median flow during 1983-2008 


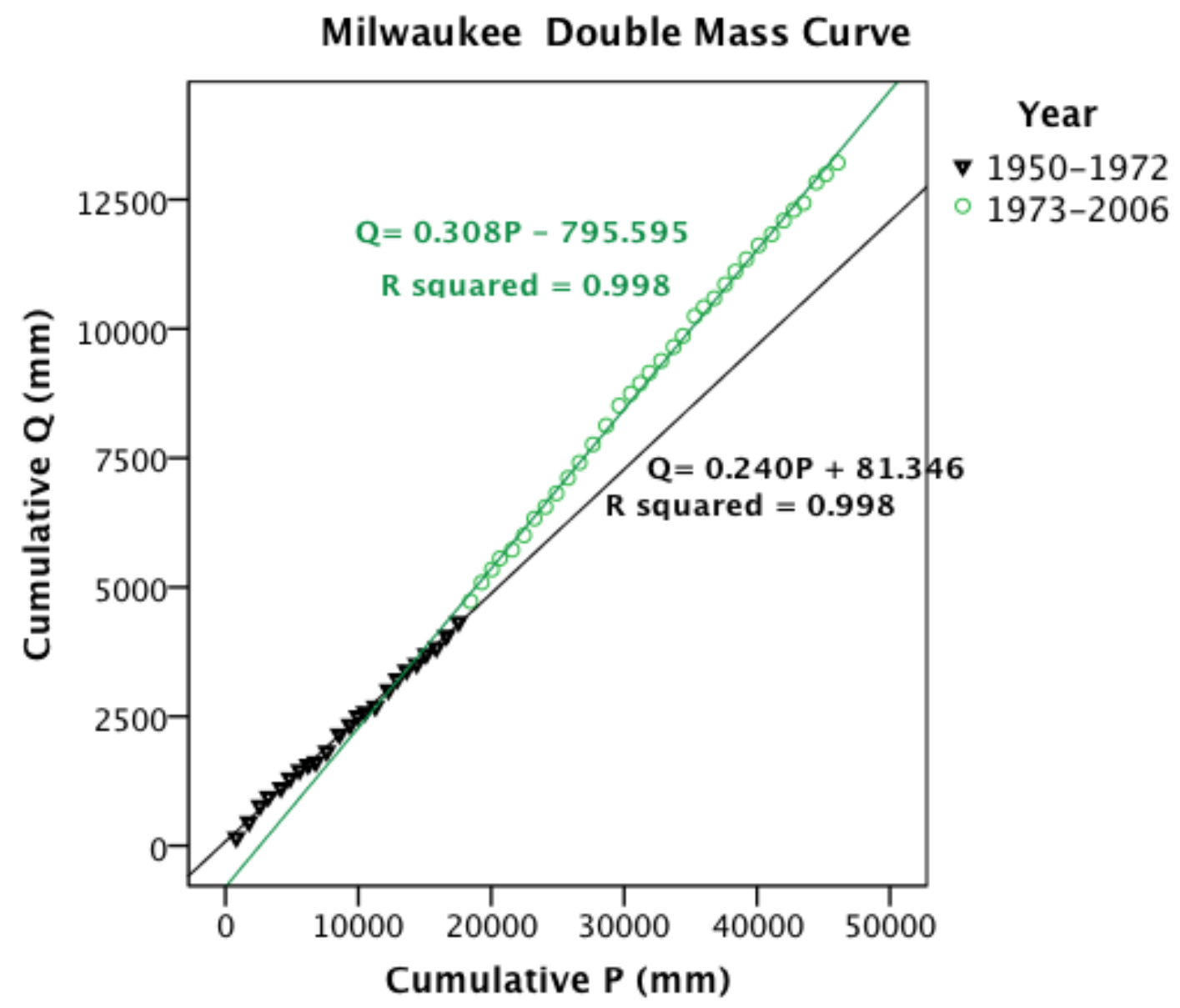




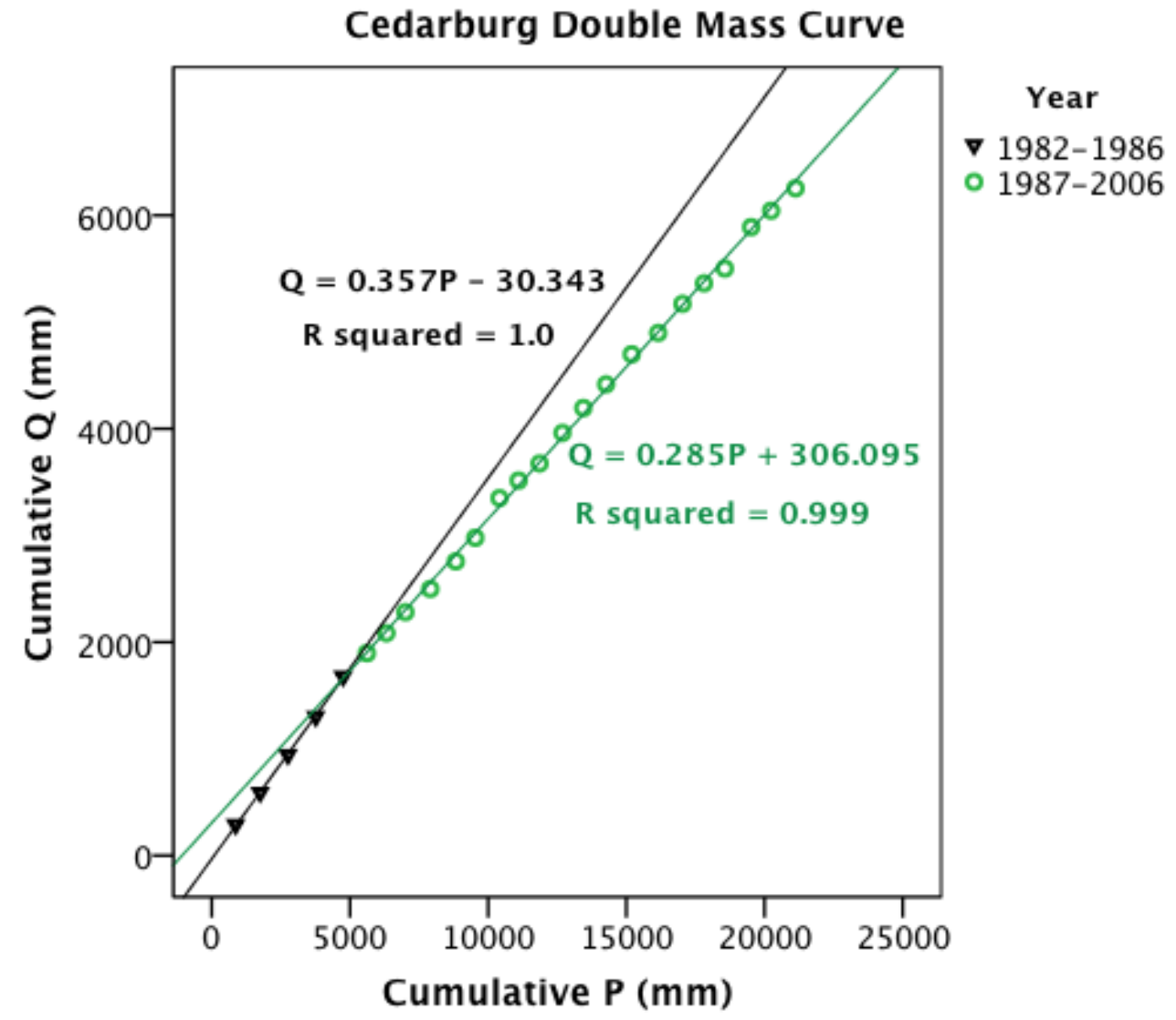




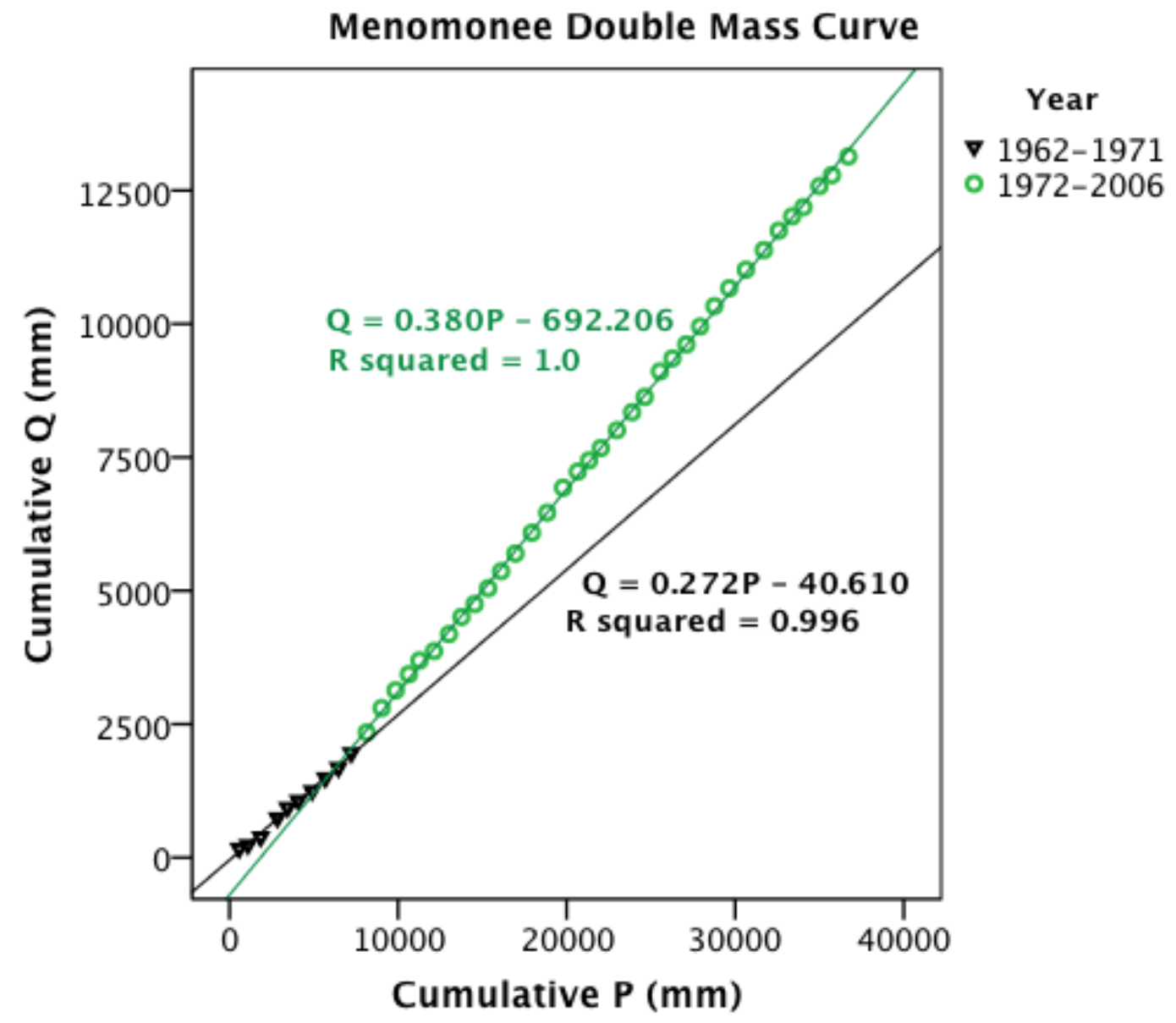




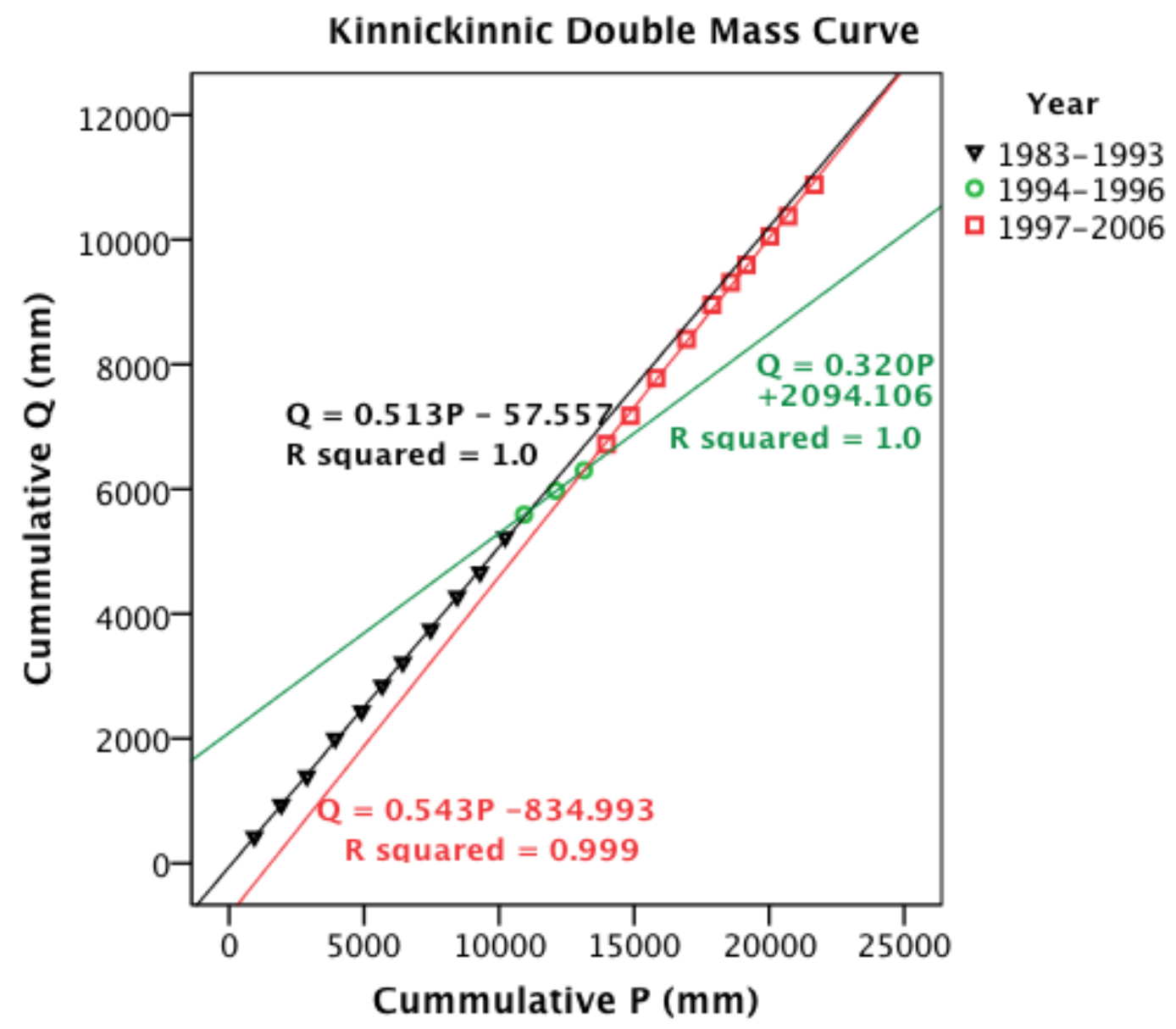

546 Figure 7. Double mass curves between cumulative precipitation (P) and runoff $(\mathrm{Q})$ for the 547 four catchments 